\title{
Antibacterial Activity of Anacaridum Occidentale on Some Enterotoxin Producing Bacteria
}

\author{
M. O. Arekemase (Corresponding author) \\ Department of Microbiology, University of Ilorin, Ilorin, Kwara state, Nigeria \\ Tel: 234-803-042-0658Ｅmail: arekemase.om@unilorin.edu.ng \\ G. P. Oyeyiola
}

Department of Microbiology, University of Ilorin, Ilorin, Kwara state, Nigeria

Tel: 234-033-597-100Ｅmail: ganiyu@unilorin.edu.ng

\author{
M. B. Aliyu \\ Department of Science Laboratory Technology \\ Federal Polytechnic, Bida, Niger State, Nigeria \\ Tel: 234-803-686-4945Ｅmail: alymb2004@yahoo.com
}

Received: April 25, 2011 Accepted: May 10, 2011 doi:10.5539/ijb.v3n4p92

\begin{abstract}
Primary screening of ethanolic and aqueous extracts of Anacardium occidentale (bark and leaf) for antimicrobial activity against Escherichia coli, Pseudomonas auroginosa, Shigella dysenteriae, Salmonella typhi and Staphylococcus aureus showed that ethanolic extract was more effective than aqueous extract. The minimum inhibitory concentration ranged from $0.05 \mathrm{~g} / \mathrm{ml}$ to $0.2 \mathrm{~g} / \mathrm{ml}$. The ethanolic extract was found to be bactericidal to all the test bacteria, while the aqueous extract was found to be bacteriostatic to the test bacteria with the exception of the aqueous leaf extract that was bactericidal to Salmonella typhi. The greater the concentration of the extract, the higher the antibacterial activities exerted on the isolates. Salmonella typhi was the most sucesceptible organism to the leaf extract, while Pseudomonas auroginosa was the least sucesceptible organism. Staphphylococcus aureus was the most sucescephple to the ethanolic bark extract and Escherichia coli was the least suceptible organism
\end{abstract}

Keywords: Anacardium occidentale, Bactericidal, Bacteriostatic, Phytochemicul, Therapy

\section{Introduction}

Plants have been serving animals as sources of energy, shelter and sustenance. They are also used at various functions for economic and medicinal purposes. The therapeutic use of medicinal plants in Africa dates back to the earliest time, when man used herbs in their raw and cooked forms to keep fit. Since that time the use of herbs have been known and accepted by all nations (Kafaru, 1994).

Medicinal plants represent a rich source of anti microbial agents (Mahesh and Satish, 2008). Plants generally produce many secondary metabolites which constitute an important source of microbicides, pesticides and many pharmaceutical drugs (Varaprased et al., 2009). Ogundipe et al. (1998) asserted that plant products still remain the principal source of pharrmaceutical drugs and agents used in traditional medicine.The effects of plant extracts on bacteria have been studied by a large number of researchers in different parts of the world (Ateb and Erdourul, 2003).

Jagadish et al. (2009) reported that plants are natural sources of pesticides that contribute to new pesticide development. The use of herbal preparations in the treatment of diarrhea is a common practice in many African countries including Nigeria, because western pharrmaceuticals are beyond the financial reach of the people (Sadiq et al., 2009). The use of herbal preparations is growing with 4 out of 10 Nigerians employing various remedies in a given year (Sadiq et al. 2009). A lot of studies have been carried out on the antimicrobial 
potentials of crude extract of different leaves, bark, bulbs, stems and roots (Atata and Sani, 2003; Olafimihan, 2004).

Paramashivappa et al. (2001) describes Anacardium occidentale as a tree that grows up to $15 \mathrm{~m}$ in height with thick tortuous trunk and woody branches It belongs to the family anacardiaceae, is native to Brazil and has a great economic and medicinal value (Rajseh et al., 2009) Anacardium occidentale is commonly called cashew in English, 'Kashu' in Hausa, 'Okpokpo' in Ibo and Kaju in Yoruba.It is a multipurpose tree whose leaves, stems and bark extracts are used extensively for the treatment of diarrhea, dysentery and colonic pain (Sadiq et al., 2009). It has also been reported to posses anti-diabetic, anti- inflammatory and anti-ulcerogenic properties (Akinpelu, 2001). The ethanolic extracts of cashew nuts revealed the presence of various phytochemical compounds such as triterpenoids, phenolic, flavenoids, xantoprotein and carbohydrate (Rajseh, 2009). The liquid obtained from the shell of cashew nut has wide commercial applications, biological and medicinal properties (Murphy and Sivajamban, 1985).

The medicinal properties of phytochemicals present in cashew nut have cytotoxic activity against several tumour cell limes, anti-diabetic, anti-inflammatory and analgesic effects (Kubo et al., 1993; Sokung, 2001; Pawar and Pal, 2002).

Omojasola and Awe (2004) reported the antimicrobial activity of the leaf extract of Aanacardium occidentale and Gossypium hirsutum against Escherichia coli, Shigella dysenteriae Salmonella typhimurium Stapphylococcus aureus and Pseudomonas auroginosa.

The aim of this research was to carry out laboratory studies on the potency of leaf and bark extracts of Anacardium occidentale using water and ethanol as extracting solvent on enterotoxin producing bacteria. Also to investigate which of the method of extraction is more effective against the test organisms. The isolates used include; Staphylococcus aureus Pseudomonas auroginosa, Escherichia coli and Salmonella typhi. There were significant differences between the aqueous and ethanollic extracts of both the leaf and bark $(\mathrm{p}<0.05)$.

\section{Materials and Methods}

\subsection{Collection of plant materials}

The plant materials used were the leaves and bark of Aanacardium occidentale Fresh leaves and bark of cashew were collected from Oke-Odo, along University of Ilorin permanent site road, Ilorin, Kwara State. The identification was carried out at the herbarium of the Department of Plant Biology, University of Ilorin.

\subsection{Collection of test Bacteria}

The pure cultures of test organisms were obtained from the University of Ilorin Teaching Hospital.

\subsection{Preparation of culture media}

The media used in this work were Nutrient agar and Nutrient broth. The media were prepared according to manufacturer's direction. The media were sterilized by autoclaving at $121^{\circ} \mathrm{C}$ for 15 minutes before use. Streptomycin $(0.1 \% \mathrm{~W} / \mathrm{V})$ was added to the media and cooled to about $50^{\circ} \mathrm{C}$.

\subsection{Preparation of plant extract}

The leaves and bark of Anacardium occidentale were sun dried for 14 days. Each of the sample was powdered using mortar and pestle into fine powder, this, was then wrapped with aluminium foil for various categories of extraction.

\subsubsection{Aqueous extraction}

Twenty grams of each of the powdered sample was weighed and dispensed into a sterile conical flask. One hundred milliliters of $90 \%$ ethanol was added to the powder. The conical flask was covered with cotton wool, wrapped with aluminium foil and placed on an orbiter shaker. After stirring for 24 hours at $190 \mathrm{rev} / \mathrm{min}$, the extract was filtered through whatman filter paper.This was then placed in a funnel coupled to a sterile reagent bottle. The bottle was labeled and stored in the refrigerator at $4^{0} \mathrm{C}$.

\subsubsection{Reconstitution of extracts}

The filtrate was transferred into a sterile conical flask, and exposed at room temperature for seven days in order to concentrate the extract. The filtrate was further concentrated by air drying in a Petri dish. The filtrate obtained after air drying was weighed and dissolved in $15 \mathrm{ml}$ of ethanol in order to obtain a stock solution. From this stock solution, varying amounts of reconstituted solvent extracts were obtained $(0.05 \mathrm{~g} / \mathrm{ml}, 0.10 \mathrm{~g} / \mathrm{ml}, 0.15 \mathrm{~g} / \mathrm{ml}$ and $0.2 \mathrm{~g} / \mathrm{ml})$. 


\subsection{Anti bacterial susceptibility test}

The antibacterial activities of the different concentrations of the different extracts on the test bacterial isolates were determined by employing the agar diffusion method of Irobi et al., (1994). Twenty milliliters of sterile Nutrient agar in petri dishes were seeded with different concentrations of standardized inocula using sterile cotton swabs. Wells of $6.0 \mathrm{~mm}$ in diameter were cut out on the seeded plates using sterile cork borer and each of the well was filled with the plant extracts of varying concentrations. The extracts were allowed to diffuse into the medium and the plates were incubated at $37^{\circ} \mathrm{C}$ for 24 hours. The zones of inhibition were measured using veneer caliper. The zones of inhibition which showed the effects of the antibacterial activity were determined around the wells. The actual zone of inhibition was calculated by subtracting the diameter of the respective discs of approximately $5 \mathrm{~mm}$ (Coyle, 2005). Controls were also set up with water or ethanol poured into each well with no plant extract.

\subsection{Determination of minimum inhibitory concentration (MIC) and minimum Bactericidal concentration (MBC)} of the plant extract.s

The method of jams (1987); Akinpelu and Kolawole (2004) and Adegboyega et al. (2008) was employed. The minimum inhibitory concentration of the aqueous and ethanolic plant extracts were determined using the test tube dilution method. A series of test tubes containing sterile culture medium and various concentrations of each extract were used. The lowest concentration that prevented growth completely was used for the determination of minimum inhibitory concentration.

Different concentrations of each extract $(0.05 \mathrm{~g} / \mathrm{ml} ; 0.1 \mathrm{~g} / \mathrm{ml} ; 0.15 \mathrm{~g} / \mathrm{ml}$ and $0.2 \mathrm{~g} / \mathrm{ml})$ were drawn from each extract and poured into $9 \mathrm{ml}$ sterile broth in each test tube, $0.5 \mathrm{ml}$ of each test bacterium was introduced into each test tube. These test tubes were incubated at $37^{\circ} \mathrm{C}$ for 24 hours. The least concentration of the extract which produced visible growth or turbidity was taken as the minimum inhibitory concentration (Olorundare et al., 1992).

The materials from each test tube used in the minimum inhibitory concentration assay that showed no growth after incubation, were streaked onto a solid nutrient agar plate and then incubated at $37^{\circ} \mathrm{C}$ for 24 hours. The lowest concentration of the extract that showed no growth on the plate after 24 hours was taken as the minimum bactericidal concentration (Alade and Irobi, 1993).

\section{Results and Discussion}

The zones of inhibition were observed around the wells, this indicated antibacterial activities of the plant extracts. The sensitivity of the different test organisms to aqueous and ethanolic extracts of both the leaves and bark of Anacardium occidentale was shown by zones of inhibition after 24 hours of incubation. This is depicted in Figures 1-4.

The absence of zones of inhibition around each well signified resistance. It was observed that the extractants (water and ethanol) used as control did not inhibit the growth of any of the test bacteria.

The minimum inhibitory concentration (MIC) was observed by lack of turbidity in each test tube used for the minimum inhibitory concentration test after 24 hours at $37^{\circ} \mathrm{C}$ (Table 1)

While the appearance of tubidity indicated the growth of test organism. The effects of the extracts were also observed. The ethanolic extracts of the bark and leaves showed potency in their bactericidal action, when compared to aqueous extract which were bacteriostatic against all the test bacteria with the exception of Salmoealla typhi where the leaf aqueous extract was bactericidal. It was observed that the control, showed no effect on the test bacteria.(Table 2) There were signfiicant differences in the antimicrobial effects of extracts obtained from leaves and bark of Anacardium occidentales using water and ethanol as extractants as presented in Tables 3 and 4 .

The ethanolic extracts of both bark and leaves of Anacardium occidentale were more effective than the aqueous extracts (Figures 1-4). This might be due to the ability of the solvent to extract more of the active ingredients (bioactive compounds) from the plant materials. The traditional preparation of decoction from medicinal plants for the treatments of various diseases involves water (cold or hot) or ethanol extraction of parts of plants such as roots, stems, bark and leaves. The above observation suggests that the active ingredients from the bark and leaves of Anacardium occidentale are more soluble in ethanol than in water (Figures 1.4). This concurs with the work of Duke (2002) who reported that several investigations on medicinal plants indicated that organic solvents such as ethanol and methanol are extensively used for crude extraction, before being re-extracted to obtain purified active compounds. 
The higher potency of ethanol extracts might be connected with the extraction solvent. Ethanol has been shown to have a greater extractive power than water. This present work agrees with the work of Awe and Omojasola (2004) they found the presence of ethanol in addition to achieving better extraction, may also enhance the efficacy of the active ingradients.

This research suggest that ethanolic extracts of screened plants would be helpful in treating diseases in man caused by enterotoxin producing bacteria namely; Salmonella typhi, Pseudomonas auroginosa, Escherichia coli Shigella dysentariae and Staphylococcus aureus. The antibacterial activities of the extracts increased as the concentration increased as found out in this work. This does not differs from the research findings of Banso and Adeyemo (2007) they reported that the tannins isolated from medicinal plants possess remarkable toxic activity against bacteria and fungi and may assume pharmacological importance in future. The potentials of any drug depends on the active principle present in it. The results obtained from this research tend to confirm the efficacy of the extracts of the bark and leaves of Anacardium occidentale as a traditional remedies against enterotoxin producing bacteria.

\section{Conclusions}

Anacardium occidentale may be effective in the treatment of disease or intoxication caused by the organisms used in this research and may contribute to the improvement of health care delivery in the country. Nigeria .If the active chemical compounds capable of inhibiting the growth of the test bacteria are analyzed and compounded into dosage forms for use.

Further studies need to be carried out to bring out the potentials of this plant in managing diarrhea, intoxication and other related gastrointestinal diseases.

\section{References}

Adegboyega, M. F.Akinpelu, D. A. and Okoh, A. I. (2008). The bioactive and phytochemical properties of G. kola (hackle) seed extract on some pathogens. African Journal of Biotechnology, 7(21): 3934-3938.

Adeleye, I. A and Ogunwale, O. O. (2004). Isolation and antibiotic susceptibility of aerobic bacterial pasthogen associated with wound infections in Lagos. Bioscience Research communication, 16(1): 1-5.

Akinpelu, D. A. (2001). Antimicrobial activity of Anarcardium occidentale bark. Fitoterapia, 72 (3): 286-287. http://dx.doi.org/10.1016/S0367-326X(00)00310-5

Akinpelu, D. A. and Kolawole, D. O. (2004). Phytochemistry and antimicrobial activity of Piliostigma thonningii 1 (Schum). Science Focus, 7: 64-70.

Alade, P. I and Irobi, O. N. (1993). Antimicrobial activities of crude leaf extract of acalypha. Wilkesiana Journal of Ethnopharmacology, 39: 171-174. http://dx.doi.org/10.1016/0378-8741(93)90033-2

Atata, R. F. and Sani, H. (2003). Effects of stem bark extracs of Enantia chloranta on some clinical isolates Biokemistri. 15: 84-92.

Ateb, D. A. and Erdourul, O. T. (2003). Antimicrobial activities of various medicinal and commercial plant extracts. Turkey Journal of Biology, 27: 157-162.

Banso, A and Adeyemo, S. O. (2007). Evaluation of antimicrobial properties of tannins isolated from Dichrostachys cinerea. African Journal of Biotechnology, 6(15): 1785-87.

Coyle, M. B. (2005). Manual of antimicrobial susceptibility testing.American Society for Microbiology (ASM) press; CD-ROM. www.ASM.org.

Duke, J. (1985). Handbook of Medicinal plants CRC Press, U.S.A. 222pp.

Fatoba, P. O. Omojasola, P. F., Awe, S. and Ahmed, F. G. (2003). Phytochemical screening of some selected tropical African Mosses. NISEB Journal, 3(2): 49-52.

Irobi, O. N. Moo-Young, M. Anderson, W. A. (1994). Antimicrobial activity of Annato (Bixa orellan) extract. The International Journal of Pharmacognosis, 34: 87-90. http://dx.doi.org/10.1076/phbi.34.2.87.13201

Jagadish, L. A. Kumar, V. K. and Kaviyarasam, V. (2009). Effect of Triphala on Dentai Bio-film. Indian Journal of Science Technology, 2(1): 30-33.

Jams, A. D. (1987). Handbook of Medicinal Herbs. Macmillan Publishers. Ibadan, pp 40-48.

Kafaru, E. (1994). Immense help from natures workshop. Elikaf Health Services Ltd. Ghana. 
Kubo. I. M., Ochi, P. C., Vieira C and S. Komatsu. (1993). Antitumor agent from the cashew Anacardium occidentale apple juice, Journal of Agricultural Food Chemistry, 41; 1012-1015. http://dx.doi.org/10.1021/jf00030a035

Mashesh, B. and Satish, S. (2008). Antimicrobial activity of some important medicimal plants against plant and human pathogens. World Journal of Agricultural Science, 4(5): 839-843.

Murthy, B. G. K. and Sivasamban, A. (1985). Recent trends in cashew nut shell liquid utilization Cashew Research and Development, Proceeding of the International Cashew Symposium. Cochin, Kerala, India. Pp 12-15.

Ogundipe, O., Akinbiyi O. and Moody, J. O. (1998). Antibacterial activity of isolates from Piper longunm and Taxus bakata. Pharmaceutical biology, 39: 236-238.

Olafimihan, G. A. (2004). Effects of seasonal variation on the antibacterial activity of aqueous extract of Azadirachta indica fresh stem bark. Bioscience Research Communications, 16(1): 13-16.

Olorundare, O. E., Emudianugbe, T. S., Khasar, G. S., Kuteji, S. A., Irobi, O. N. (1992). Antimicrobial activities of leaf extract of Cassia alata. Bioscience Research Communication, 4(2): 113-117.

Omojasola, P. F. and Awe S. (2004). The antibacterial activity of the leaf extracts of Anacardium occidentale and Gossypium hirsutun against some selected microorganisms. Bioscience Research Communications, 60(1): 25-58.

Paramashivappa, R., Phain, K. P., Vithay Athil, P. J. and Rao, A. S. (2001). Method for Isolation of major Phenolic consitutents from cashew (Anacardium occidentale L.) nut shell liquid. Journal of Agricltural Food Chemistry, 49(5): 2548-2551. http://dx.doi.org/10.1021/jf001222j

Pawar, S and Pal. S. C. (2002). Analgesic and anti-inflammatory activity of Anacardium occidentale root extracts. Hamdard-Medicus, 45(4): 63-68.

Rajash K, V. S. Sumathi, C. S., Balasubramanian, V and Ramesh, N. (2009). Elementary chemical Profiling and antifungal properties of cashew (Anacardium occidentale L.) nuts Botany Research International, 2(4): 253-257.

Table 1. Minimum inhibitory concentration of the extracts

\begin{tabular}{|c|c|c|c|c|c|c|}
\hline \multirow{2}{*}{\begin{tabular}{c}
$*$ \\
\multirow{2}{*}{ Test organisms }
\end{tabular}} & \multicolumn{4}{|c|}{ Minimum Inhibitory Concentrations (g/ml) } & \multicolumn{2}{c|}{ Control } \\
\cline { 2 - 7 } & EBE & ELE & ABE & ALE & Water & Ethanol \\
\hline Escherichia coli & 0.10 & 0.10 & 0.15 & 0.20 & Nil & Nil \\
\hline Staphylococcus aureus & 0.10 & 0.10 & 0.15 & 0.15 & Nil & Nil \\
\hline $\begin{array}{c}\text { Pseudomonas } \\
\text { aeruginosa }\end{array}$ & 0.10 & 0.10 & 2.00 & 0.20 & Nil & Nil \\
\hline Shigella dysentariac & 0.10 & 0.10 & 0.15 & 0.15 & Nil & Nil \\
\hline Salmonella typhi & 0.05 & 0.10 & 0.15 & 0.10 & Nil & Nil \\
\hline
\end{tabular}

Key:

EBE Ethanolic Bark Extract

ELE Ethanolic Leaf Extract

ABE Aqueous Bark Extract

ALE Aqueous Leaf Extract

NIL No Effect 
Table 2. Bactericidal and bacteriostatic effects of Anacardium occidentale extract (bark and leaf)

\begin{tabular}{|c|c|c|c|c|c|c|}
\hline \multirow{2}{*}{ Test organisms } & \multicolumn{4}{|c|}{ Effects of the extract } & \multicolumn{2}{|c|}{ Control } \\
\hline & EBE & ELE & $\mathrm{ABE}$ & ALE & Water & Ethanol \\
\hline Escherichia coli & $\mathrm{BC}$ & $\mathrm{BC}$ & BS & $\mathrm{BS}$ & Nil & Nil \\
\hline Staphylococcus aureus & $\mathrm{BC}$ & $\mathrm{BC}$ & BS & BS & Nil & Nil \\
\hline $\begin{array}{c}\text { Pseudomonas } \\
\text { aeruginosa }\end{array}$ & $\mathrm{BC}$ & $\mathrm{BC}$ & $\mathrm{BS}$ & $\mathrm{BS}$ & Nil & Nil \\
\hline Shigella dysentariae & $\mathrm{BC}$ & $\mathrm{BC}$ & $\mathrm{BS}$ & $\mathrm{BS}$ & Nil & Nil \\
\hline Salmonella typhi & $\mathrm{BC}$ & $\mathrm{BC}$ & $\mathrm{BS}$ & $\mathrm{BC}$ & Nil & Nil \\
\hline
\end{tabular}

Key:

EBE: Ethanolic Bark Extract

ELE: Ethanolic Leaf Extract

ABE: Aqueous Bark Extract

ALE: Aqueous Leaf Extract

B.C: Bactericidal: when low extract concentration inhibited bacterial growth

B.S: Bacteriostatic: when high extract concentration inhibited bacterial growth

NIL: No Effect

Table 3. Multiple range test for the effects of medium of extraction on leaf of Anacardium occidentale against some selected microorganisms

\begin{tabular}{|c|c|c|c|c|c|c|c|c|}
\hline \multirow{2}{*}{ Organism } & \multicolumn{9}{|c|}{ Concentration in $\mathrm{g} / \mathrm{ml}$} \\
\cline { 2 - 10 } & \multicolumn{2}{|c|}{0.05} & \multicolumn{2}{c|}{0.10} & \multicolumn{2}{c|}{0.15} & \multicolumn{2}{c|}{0.20} \\
\cline { 2 - 10 } & Water & Ethanol & Water & Ethanol & Water & Ethanol & Water & Ethanol \\
\hline Salmonella typhi & $3.5^{\mathrm{a}}$ & $5.8^{\mathrm{b}}$ & $3.5^{\mathrm{a}}$ & $5.4^{\mathrm{b}}$ & $7.5^{\mathrm{a}}$ & $9.7^{\mathrm{b}}$ & $9.0^{\mathrm{a}}$ & $12.3^{\mathrm{b}}$ \\
\hline $\begin{array}{c}\text { Staphylococcus } \\
\text { aureus }\end{array}$ & $2.8^{\mathrm{a}}$ & $6.1^{\mathrm{b}}$ & $3.5^{\mathrm{a}}$ & $9.7^{\mathrm{b}}$ & $6.8^{\mathrm{a}}$ & $11.1^{\mathrm{b}}$ & $8.8^{\mathrm{a}}$ & $11.3 \mathrm{~b}$ \\
\hline $\begin{array}{c}\text { Shigella } \\
\text { dysenteriae }\end{array}$ & $3.5^{\mathrm{a}}$ & $4.9^{\mathrm{b}}$ & $3.4^{\mathrm{a}}$ & $6.2^{\mathrm{b}}$ & $5.5^{\mathrm{a}}$ & $9.8^{\mathrm{b}}$ & $6.6^{\mathrm{a}}$ & $6.7^{\mathrm{a}}$ \\
\hline $\begin{array}{c}\text { Pseudomonas } \\
\text { auroginosa }\end{array}$ & $3.5^{\mathrm{a}}$ & $3.5^{\mathrm{a}}$ & $5.4^{\mathrm{a}}$ & $5.6^{\mathrm{a}}$ & $5.5^{\mathrm{a}}$ & $6.2^{\mathrm{b}}$ & $5.6^{\mathrm{a}}$ & $8.2^{\mathrm{b}}$ \\
\hline Escherichia coli & $2.7^{\mathrm{a}}$ & $3.1^{\mathrm{b}}$ & $2.8^{\mathrm{a}}$ & $5.7^{\mathrm{b}}$ & $4.9^{\mathrm{a}}$ & $5.5^{\mathrm{b}}$ & $3.9^{\mathrm{a}}$ & $3.9^{\mathrm{a}}$ \\
\hline
\end{tabular}

Means labeled with different superscripts across a row are significantly different $(\mathrm{p}<0.05)$

Table 4. Multiple range test for the effects of medium of extraction on bark of Anacardium occidentale against some selected microorganisms

\begin{tabular}{|c|c|c|c|c|c|c|c|c|}
\hline \multirow{2}{*}{ Organism } & \multicolumn{9}{|c|}{ Concentration in $\mathrm{g} / \mathrm{ml}$} \\
\cline { 2 - 9 } & \multicolumn{2}{|c|}{0.05} & \multicolumn{2}{c|}{0.10} & \multicolumn{2}{c|}{0.15} & \multicolumn{2}{c|}{0.20} \\
\cline { 2 - 9 } & Water & Ethanol & Water & Ethanol & Water & Ethanol & Water & Ethanol \\
\hline Salmonella typhi & $5.3^{\mathrm{a}}$ & $7.4^{\mathrm{b}}$ & $3.4^{\mathrm{a}}$ & $9.1^{\mathrm{b}}$ & $9.6^{\mathrm{a}}$ & $11.6^{\mathrm{b}}$ & $11.8^{\mathrm{a}}$ & $12.6^{\mathrm{b}}$ \\
\hline $\begin{array}{c}\text { Staphylococcus } \\
\text { aureus }\end{array}$ & $3.0^{\mathrm{a}}$ & $4.6^{\mathrm{b}}$ & $3.4^{\mathrm{a}}$ & $7.4^{\mathrm{b}}$ & $7.1^{\mathrm{a}}$ & $10.1^{\mathrm{b}}$ & $10.5^{\mathrm{a}}$ & $11.3^{\mathrm{b}}$ \\
\hline $\begin{array}{c}\text { Shigella } \\
\text { dysenteriae }\end{array}$ & $5.5^{\mathrm{a}}$ & $5.6^{\mathrm{a}}$ & $5.5^{\mathrm{a}}$ & $7.2^{\mathrm{b}}$ & $6.1^{\mathrm{a}}$ & $9.8^{\mathrm{b}}$ & $9.9^{\mathrm{a}}$ & $10.6^{\mathrm{b}}$ \\
\hline $\begin{array}{c}\text { Pseudomonas } \\
\text { auroginosa }\end{array}$ & $2.2^{\mathrm{a}}$ & $3.9^{\mathrm{b}}$ & $3.0^{\mathrm{a}}$ & $5.7^{\mathrm{b}}$ & $3.9^{\mathrm{a}}$ & $3.9^{\mathrm{b}}$ & $4.5^{\mathrm{a}}$ & $4.6^{\mathrm{a}}$ \\
\hline Escherichia coli & $5.6^{\mathrm{a}}$ & $7.3^{\mathrm{b}}$ & $4.5^{\mathrm{a}}$ & $5.6^{\mathrm{b}}$ & $7.3^{\mathrm{a}}$ & $9.2^{\mathrm{b}}$ & $8.2^{\mathrm{a}}$ & $9.3^{\mathrm{b}}$ \\
\hline
\end{tabular}

Means labeled with different superscripts across a row are significantly different $(\mathrm{p}<0.05)$ 


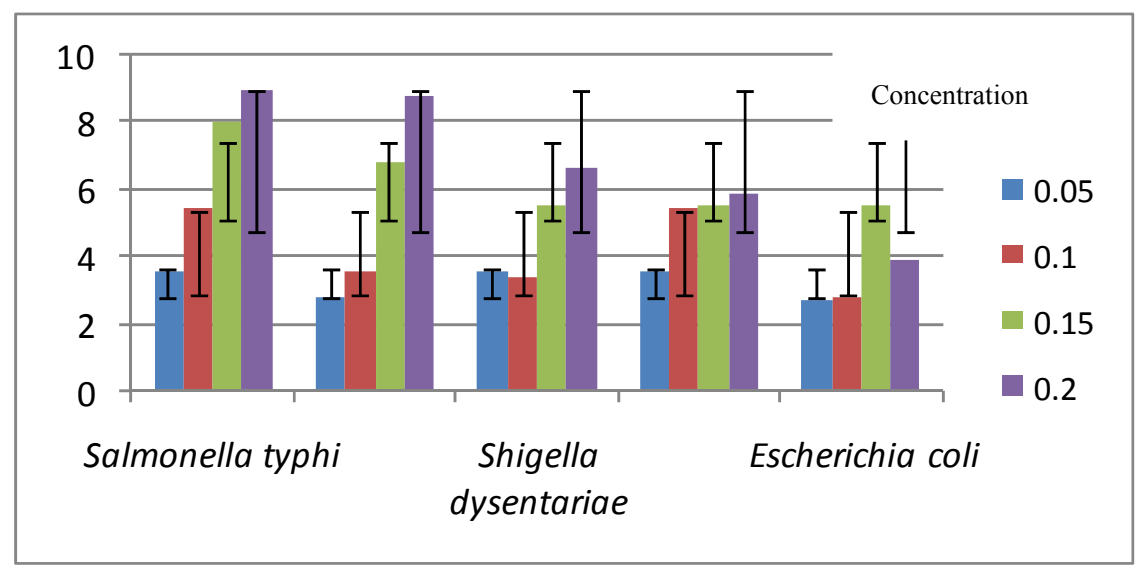

Figure 1. Antibacterial activity of aqueous bark extract of Anacardium occidentale against some selected bacteria

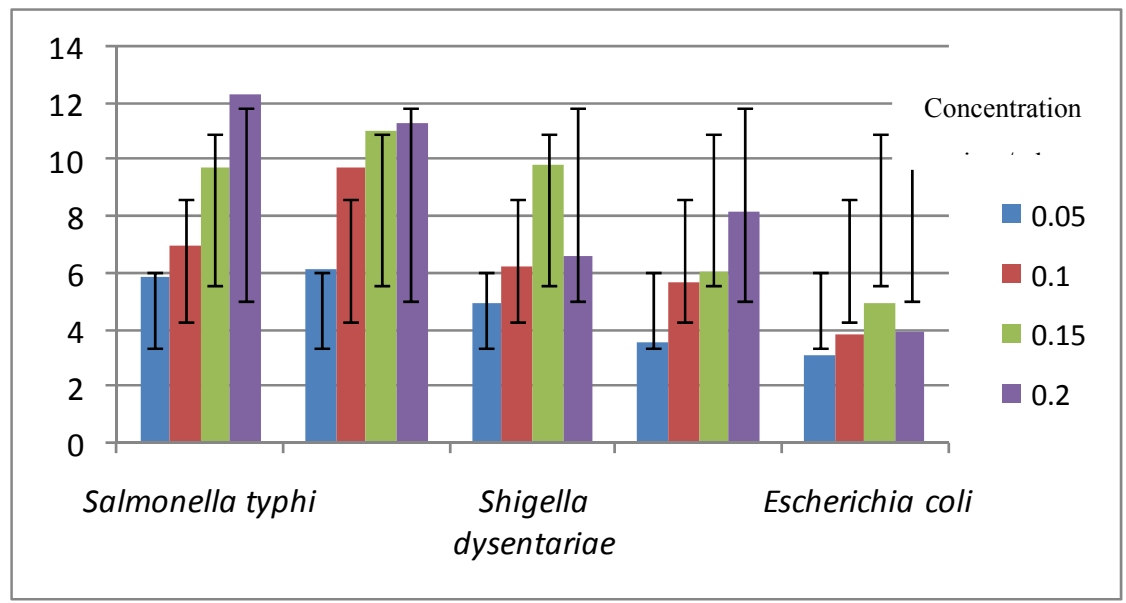

Figure 2. Antibacterial activity of ethanolic extract of Anacardium occidentale against some selected bacteria

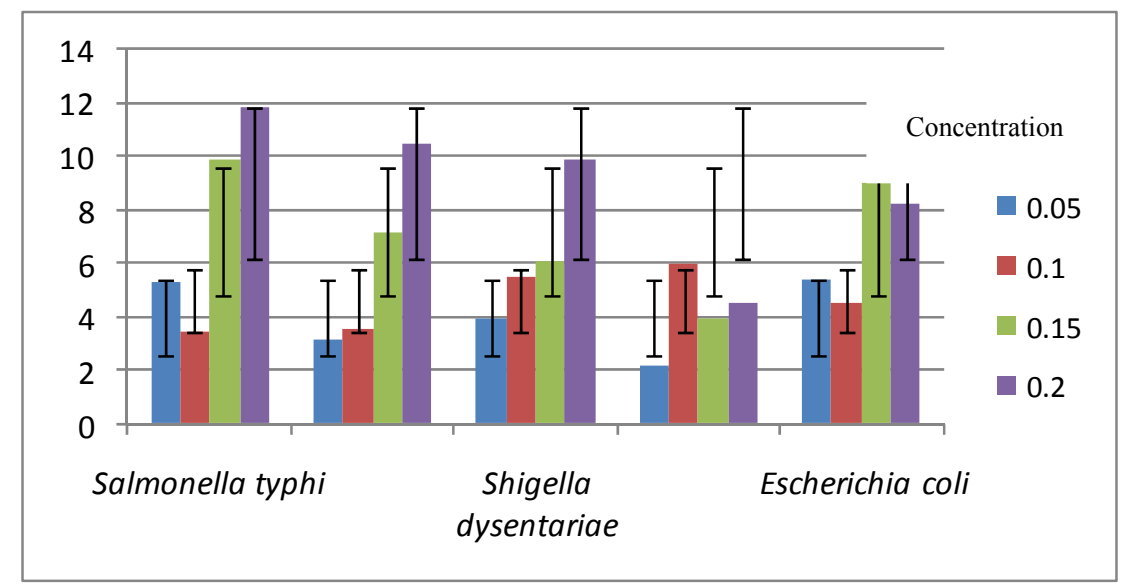

Figure 3. Antibacterial activity of aqueous leaf extract of Anacardium occidentale against some selected bacteria 


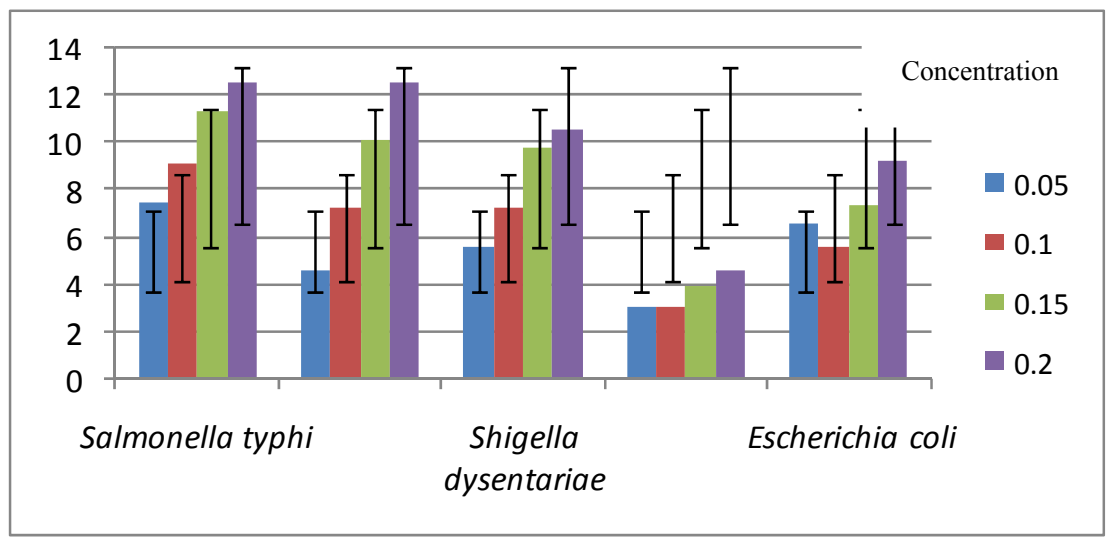

Figure 4. Antibacterial activity of ethanolic extract of Anacardium occidentale against some selected bacteria 